\title{
Trade Liberalization, Economic Reforms and Foreign Direct Investment - A Critical Analysis of the Political Transformation in Vietnam
}

\author{
Van Chien Nguyen ${ }^{1}$ \\ ${ }^{1}$ Thu Dau Mot University, Vietnam \\ chiennv@tdm.edu.vn\&chienmpp3@gmail.com
}

\begin{abstract}
The purpose of this study is to discuss the trends of integration into the global economy since political and economic reforms (so-called Doimoi) and its influence on every presence of foreign investment in Vietnam. Lasting 20-year-war period and ended in 1975 , by the mid-1980s per capita income was stuck between \$200 and \$300, Vietnam's government introduced Doimoi through a series of reforms, and steered the country to be a socialist-oriented market economy. Based on the analysis of reform process and integration, the results are concerned. Our results demonstrate that foreign direct investment performance has significantly embraced trade liberalization with gusto. Further, the open trade policy in relation to FTAs could significantly promote foreign investment and maximize its benefits on the economy.
\end{abstract}

Keywords: Doimoi, foreign direct investment, FTAs, integration, trade liberalization

\section{Introduction}

In the trend of global economic integration, receiving international capital flows through FDI inflows has been such a major resource of economic growth for each country's economy. Those capital inflows have complemented resources about capital, technology as well as modern management skills in particularly developing country (Nguyen; 2018; Nguyen, 2020a). Most less developed countries lack of investment capital for improving high economic growth in order to shorten the distance with developed countries. In particular, the attraction of foreign direct investment (FDI) inflows as well as a significant role in industry sector and the process of technology transfer (OECD, 2002), through multinational corporations (MNCs) that is considered to be a major channel for the access to high technologies (Tybout, 2000; Nguyen, 2018). Therefore, local firms in host countries can enhance productivity and production efficiency, and joining global value chains. On the other hand, FDI enhances export activities, making economy really becomes more dynamic. The success of China's export led policy to make this country getting better in economic growth rate over the past long period. Exports boost domestic trade expansion as well as sufficient resource allocation in production.

Vietnam is currently one of the dynamic emerging countries with great potential in Asia. FDI attraction is one of the highest priorities of the policy makers in the country (Van \& Do, 2020). As a result of FDI attraction since political and economic reform (socalled Doimoi) in 1986 to the present, foreign capital has become a major driver of Vietnam's growth. By 2019, Vietnam has attracted 30,827 valid FDI projects with the total registered capital of roughly USD362 billion, and invested from 135 countries and territories, of which South Korea, Japan, Singapore, Taiwan are major investors.

In agreement with the political and economic integration, Vietnam has robustly advocated more open trade policy and singed more free trade agreements (FTAs) in order to promote investment, trade, and renovation. The country has witnessed another record FDI inflows and trade performance of close to US\$30 and US\$500 billion in 2019, but in the report of AmCham Vietnam (2016) also emphasizes that Vietnamese economy is too 
dependent on external demand in the forms of foreign investment and exports. AmCham Vietnam (2016) also describes that the failure of local businesses reflect their poor internal strength, re-balancing the economy towards internal demand in the forms of exports has not been achieved yet. Further, many foreign companies in Vietnam have attempted to find domestically in order to decrease production costs and maximize profit. However, many local businesses have not been able to join the global value chain through multinational firms in order to absorb their productivity and technological innovation.

Based on these arguments, this aim of this study is to analyze the effects of the process of political and economic reforms, and the trade policy in relation to FTAs in the country. Regarding the methodology, this study is to employ qualitative methods, in which the study will analyze the integrated process in Vietnam since economic reforms in 1986 to the present. This paper is organized as follows. Following this Introduction, Section 2 presents briefly the literature review. Section 3 discusses the data and data sources, methodology development. Further, Section 4 indicates the empirical findings and discussions, followed by Conclusions in Section 5.

\section{Literature Review}

In the present context of the world, the receipt of international capital flows through FDI inflows are an important source of economic growth in the economy of any country and, as a result of that, FDI inflows have supplemented to domestic resources such as capital, technology and knowledge improvement and managerial skills and productivity growth particularly from the perspective of a developing country (Harrison, 1994; Mun at el., 2008; Nguyen, 2020a).

However, it is found that most less- developed countries do not have adequate investment in order to sustain a high economic growth toward the minimization of the gap that exists between the developing and developed countries. In particular, the attraction of FDI inflows also play a crucial role in the industry sector in addition to the technology transfer process (Wang, 1990; Tybout, 2000; Nguyen, 2018), which is a major channel to access to new technologies (Du at el., 2012; Chaudhry at el., 2013) and export promotion (Harrison \& Rodríguez-Clare, 2010). Therefore, local firms in host countries get the opportunity to enhance productivity and production efficiency and join the global value chain. To be more precise, inward FDI flows accelerate exports (Aitken at el., 1997; Nguyen, 2020b). It means that only the productive firms choose to serve in the foreign markets via FDI when less productive firms self-select domestically-oriented markets (Helpman at el., 2004).

Shen at el. (2019) indicate that cost minimization for a specific country to change from the planned economy to the market economy is totally dependent upon a combination of the speed and the specific reform strategy. It is noted that the inflows of FDI to China have marked a significant role in its economic development and export success. According to OECD (2000) on economic reform since 1979, China has been able to secure a large proportion of international direct investment flows. World Bank (2010) confirms that FDI inflows have not only accounted for over haft of trading in China and the rest of the world, but also contributed to one-third of China's industrial output. There are some other instances in which FDI inflows have strengthened the institutional capacity also. Currently, Vietnam is identified as a developing country in the dynamic region of Asia with a political system similar to that of China and also as a country that has reformed its economy in order to attract more foreign investment to the country. Dependent upon the FDI attracted in the period of 1986 - 2019, Vietnam has invested FDI inflows with 30,827 valid FDI projects consistent with the number registered capital at US\$362 billion. 


\section{Data Sources and Methodology}

\subsection{Data Sources}

The data used in this study are collected since 1986 till present. All data are retrieved from the General Statistics Office of Ministry of Planning and Investment, and Ministry of Finance, State Bank of Vietnam, and World Bank's World Development Indicators. The data include every presence of foreign investment, and the trade liberalization process in relation to FTAs.

\subsection{Methodology}

Impact of economic reform and trade liberalization on foreign investment has been discussed in numerous of empirical studies. Followed by theoretical consideration, the research model is described as follows:

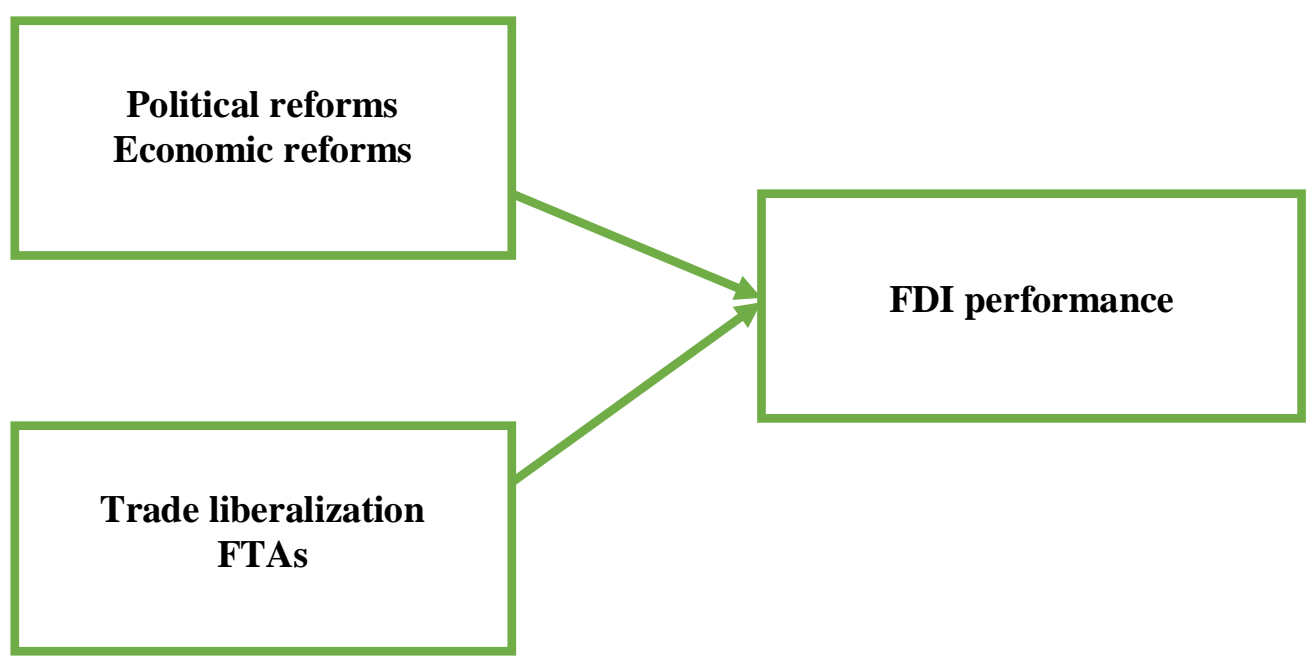

Figure 1. Research Model

In order to discover the analysis of the relationship, we hypothesize the following model:

FDI performance $=\mathrm{f}($ Political reforms, Economic reforms, Trade liberalization, FTAs $)$

Where:

- Political reforms, Economic reforms, Trade liberalization, FTAs are the independent variable. This can be abbreviated by political and economic reforms, trade liberalization, FTAs.

\section{Results and Discussion}

\subsection{Economic reforms and FDI inflows attractive policy}

It is notable that Vietnam's economy had been devastated to a great extent due to the 30-year war. After the war in 1975, the embargo by USA and its allies on Vietnam economy had negatively caused many hardships and difficulties on trade, investment and most of aspects of the economy in addition to the devastation caused by the 30 year war. It is not an exaggeration to note that there had been no foreign investment in Vietnam during this time. In reality, although the Foreign Investment Rules in 1977 had announced to draw foreign investment but FDI inflows had not poured into the county due to unfavorable situations in politics and international relationships (Nguyen, 2018). 
In the case of Vietnam, the lessons of the fall of the Soviet Union and the East European countries could greatly lead it to conservatively follow a mixture of political and economic reforms that could be beginning to have a beneficial impact on the country's society (Schellhorn, 1992). It is true to mention here that these internal and external political pressures have delayed the country's economic and political reforms that are about to improve the living standards of large number of citizens with famine and poverty toward a developed nation (World Bank, 2011). As a result, with the VI Vietnam's General Assembly in 1986, it had been officially decided to perform a reform regime of national economy in transition from the socialist-demand economy to the socialist-oriented market economy with much emphasis on a journey toward liberalization of all resources to economic development.

The economic and political reforms have attempted in an effort to lift the majority of citizens by eradicating famine and poverty and promising the development of the country. Parallel to the Doimoi, the first time in the history, the official law of foreign domestic investment had been introduced in 1987. According to the law, the government had predominantly encouraged foreign companies to business in Vietnam. The country had encouraged primary-exports-led growth strategies in favor of import substitution by applying high barriers to foreign goods in order to encourage domestic production. Obviously, the economic performance after wartime had been increasingly worsened. During the socialist model from 1975 to 1986 , economy was entirely controlled by the state, the private sector had no place in industrial production and doing business. However, the result of FDI attraction during the period 1987 - 1994 had not been achieved apart from the small and medium-sized firms and firms for the production of consumer goods had been established within the period.

\section{Table 4.1. The Road of FDI Law Reform}

\begin{tabular}{|c|c|}
\hline 1977 & $\begin{array}{l}\text { Foreign Investment Rules: Government owns at least } 51 \% \text { of the company's } \\
\text { shares. }\end{array}$ \\
\hline 1987 & $\begin{array}{l}\text { Foreign Investment Law introduced in the first time: allowed for FDI doing } \\
\text { business in more sectors; (2) encouraged in export oriented production and } \\
\text { import substitution; (3) encouraged in high-used sectors, skilled labors and } \\
\text { infrastructure development. }\end{array}$ \\
\hline 1989 & Trade reform, especially removal of import duties on some indu \\
\hline 1990 & $\begin{array}{l}\text { Private Enterprise Law introduced in the first time in } 1990 \text { and enacted in } \\
1992 \\
\text { Law of Companies introduced in the first time }\end{array}$ \\
\hline 1991 & $\begin{array}{l}\text { Introduction of Export Processing Zones (EPZs) and Industrial Parks (IPs) (or } \\
\text { Economic Zones - EZs) in the first time (see Decree No. 533/HĐBT in Oct } \\
\text { 1991). }\end{array}$ \\
\hline 1992 & $\begin{array}{l}\text { Foreign Investment Law revised: (1) incentives FDIs related to local } \\
\text { enterprises, restricting 100\% FDIs and land access; (2) encourage in new } \\
\text { subsets of investment: EPZs and BOT contracts (Built-Operating-Transfer) }\end{array}$ \\
\hline 199 & State-Owned Enterprises (SOE) Law \\
\hline 1996 & w re \\
\hline
\end{tabular}




\begin{tabular}{|rl|}
\hline $\begin{array}{l}\text { capital contribution and land access; (2) incentives related to high-technology } \\
\text { industries; (3) taxation reform as exemption of import duty related to some } \\
\text { goods and inputs }\end{array}$ \\
\hline 1999 & Enterprise Law introduced in the first time, replaced for Law of Companies \\
and Law of Private Enterprise 1990
\end{tabular}

Source: Nguyen at el. (2006), McCaig \& Pavcnik (2013), and Nguyen (2018)

Since the economic reform, Doimoi was promoted to transform its economy from a central planning economy to a socialist-oriented market economy. The Doimoi process strongly influenced the development and the political and economic reform of Vietnam. Against this backdrop, participation to ASEAN and normalization of Vietnam - The United States (USA) relationship have been seen as the pressure to promote economic reform. FDIs were more likely to invest to Vietnam due to stable politics, huge workforce and geopolitical location of the country. In this trend, Vietnam has developed a system of industrial zones over the country in order to provide appropriate infrastructure and investment opportunities for investors. Table 1 describes that the FDI law had to be amended several times to meet the requirements in the country in 1990, 1992, 1996 and 2000 (Nguyen at el., 2006; McCaig \& Pavcnik, 2013; Nguyen, 2018). Further, Vietnam has performed a wide range of industries like real estate, transportation, banking, tourism and others by numerous form of investment, i.e. business corporate contract, joint venture and purely foreign invested firms. The law for foreign direct investment needs to be amended in order to endorse. In addition, the FDI law has been renamed as the Enterprise Law since 2006, in which the law has to treat a foreign firm as equally as it does a local firm. It is interesting to note that FDI law has frequently been amended since 1990 to 1996 whereby the policy for FDI has become unstable and made foreign investors more embarrassed in doing business in Vietnam during this period. It is evident that foreign investors had not played a major role in generating employment, wealth, diversification and achievement within the period 1990 - 1995.

In face of the opportunities of FTAs and the Trans-Pacific Partnership (TPP) agreement, and a newly Vietnam- EU trade agreement, it is as a new phenomenon in the Vietnam's society. Firstly, FTAs could be expected to have a positive effect on outward 
FDI from developed countries to developing countries. In fact, FTAs in general encourage FDI by creating jobs, technology transfer, improving the balance of international payment, increasing export, access to international markets and economic growth. Consistent with these agreements, the investment law 2006 has just been amended in 2014 releasing investment registration certificate for local businesses and reducing investment registration certificate related to foreign investment with over 51 percent of ownership in all firms. In addition, the law also imposes limitations on each sector and conditional business in specific industries. In particular to the reform in the banking and financial market as well as the stock market, M\&A encourages the economic institutional reforms that will probably increase foreign direct and foreign indirect inflows. Further, this has also helped to modernize management and corporate governance through FDI so that Vietnam tends to reach the global standard in policies for FDI attraction.

\subsection{Free Trade Agreements and Its Impact on FDI inflows}

After reunified in 1975, Vietnam had experienced a period of hardships and difficulties caused by the embargo on trade, investment and almost all the aspects of the country by USA and its allies. In addition, it also bares evidence that Vietnam had maintained relationships only with the socialist nations of Central and Eastern Europe representing the typical Soviet Union (a large part of the Soviet Union is now called as Russia) and China. At the same, there had been conflicts between the Soviet Union and its Western allies parallel to the economic reforms implemented by China in 1979.

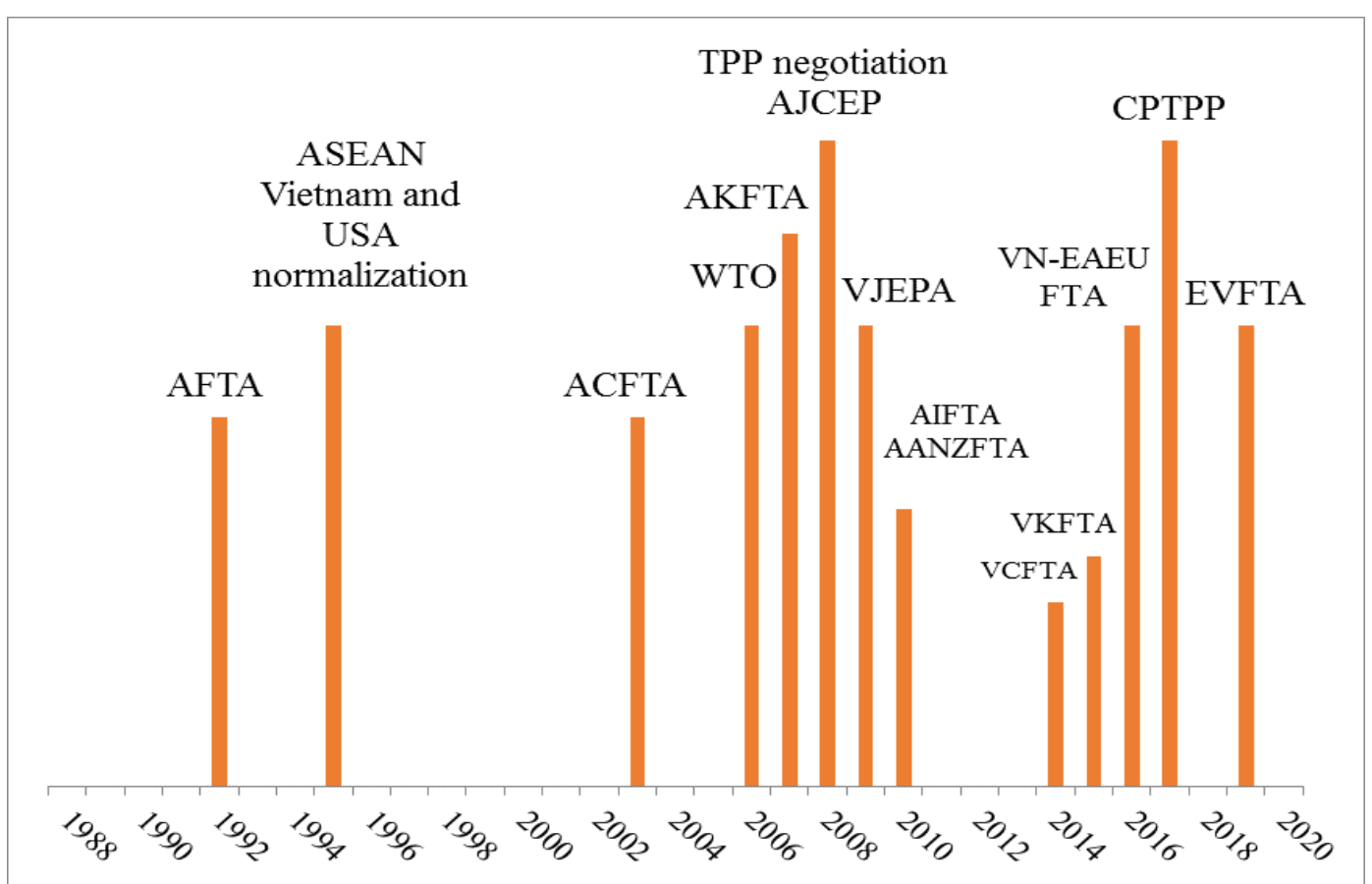

Source: Synthesis of the Author

Note: ASEAN, WTO, TPP, CPTPP are The Association of Southeast Asian Nations, World Trade Organization, Trans-Pacific Partnership and Comprehensive and Progressive Agreement for TransPacific Partnership, respectively. Further, AFTA (ASEAN), ACFTA (ASEAN and China), AKFTA (ASEAN and South Korea), AJCEP (ASEAN and Japan), VJEPA (Vietnam and Japan), AIFTA (ASEAN and India), AANZFTA (ASEAN, Australia and New Zealand), VCFTA (Vietnam and Chile), VKFTA (Vietnam and South Korea), VN-EAEU FTA (Vietnam and Russia, Belarus, Armenia, Kazakhstan, Kyrgyzstan), EVFTA (Vietnam and EU)

\section{Figure 2. FTAs of Vietnam since Doimoi}

The first time in history December 1987, the country's official law of foreign domestic investment was introduced. Accordingly, the government has encouraged business by 
foreign companies in Vietnam. Despite, several foreign businesses that has been indirectly invested in third world countries since 1989, the result of attracting FDIs during the period 1987 - 1994 has been really modest and established almost by small and mediumsized firms of consumer goods production and final goods to cater the demand for foods.

With the rapid growth of Vietnam in the 1990s, the country's reforms have been on a relatively low base. The success of Vietnam's FDI inflows has been with the process of opening and deeply integrating into the global economy under four major milestones. In connection with many years of negotiation, Vietnam has officially joined The Association of Southeast Asian Nations (ASEAN) in August 1995. Especially, during the same period, the United States has somewhat its attitude toward Vietnam and cancelled the restrictions that kept Vietnam away from United States (USA) and its allies and the rest of the world. This enabled Vietnam to be further closer to USA and the world and led to FDI's attraction since 1995 with an economic growth rate at 9.54\% in 1995 and $9.34 \%$ in 1996 (Nguyen, 2018).

Figure 2 describes the process of the participation of FTAs and the integration with the global economy in the period 1986 to the present. The results from the integration process show that Vietnam managed to attract significant inflows of FDI quickly through the establishment of Industrial Parks (IPs) and Export Processing Zone (EPZ) across the country. Approximately 67 IPs and EPZ have been developed so far to 2002, where there is a purely foreign-owned industrial zone, 14 joint ventures and 52 Vietnamese owned industrial zones (Le, 2002). After 10 years of negotiation, Vietnam has been able to reach the 150th position in the World Trade Organization (WTO). In general, WTO membership has had a positive impact on the economy by trade expansion to major trade partners such as China, USA, European or East Asian countries. However, the evaluation of WTO on trade and FDI inflows are considered very important in order to calculate the effects of the existing agreement and other FTAs. In this effort, Vietnam had first to release tariff reductions, trading rights, tariff rate quotas, export restrictions related to many sectors (Cling at el., 2008). According to Frankel and Rose (2002) on 200 countries and dependencies, there has been no significant additional impact on trade due to WTO membership despite the opportunity to create 30 percent more trade for new members absorbing the highest benefit among least developing and emerging countries (Subramanian \& Wei, 2003). Further, in line with the findings of Pham (2011), WTO accession has a significant positive effect both on FDI inflows and imports in Vietnam over the period of 1990 - 2008. Though there are no sufficient evidence, this agreement has indirectly enhanced exports by encouraging FDI inflows resulted by the constructive relationships between FDI inflows and exports as suggested by Nguyen (2018).

Vietnam initiated Trans Pacific Partnership negotiation since 2008, a free-trade agreement with its members in the Pacific Ocean as the first true 21st century trade agreement that brought extended international rules and huge opportunities expanding a broader market for Vietnam's trade with members in consent. Although, the current President of the United Stated of America, Donald Trump denounces this organization in favor of an "American First" policy, other members are actively engaged in it. All members strongly believe that TPP could probably be further negotiated, successfully approved and be the best cooperation for trade in the world targeting new members. The important point is that, TPP at the last annual 21-member APEC summit in Da Nang, Vietnam in Nov, 2017 under the Comprehensive and Progressive Agreement for TransPacific Partnership (CPTPP) with the participation of 11 remaining countries, had agreed with the core elements without United of States with the expectations of the return of the United of States in future.

In this scenario, Vietnam intends to amend existing laws ensuring the consistency with the legal code of TPP agreement with the regulations on permit worker (Froman, 2016) and respecting independent labor union for employees for greater opportunities through 
TPP. As suggested by Nikkei (2017), members in TPP trade agreement have increased Vietnam's GDP expand by 1.51 percent in 2030 for a non-US TPP. It is noted that if USA is still a member in tariff reduction scenario with US, Vietnam will acquire the most significant growth in GDP. As shown by Petri \& Plummer (2016), Vietnam's GDP in 2025 is expected to increase at least 10.5 percent and 8 percent (World Bank, 2015), the top performance in all members of TPP. Dasgupta \& Mukhopadhyay (2017) have otherwise pointed out that, if USA is omitted, Vietnam and Malaysia will certainly be the two most adversely affected economies, when textiles and apparel industry in concern, though joining TPP still creates better opportunities for a big leap for ASEAN members such as the expansion trade relations with other TPP members like Japan, Chile, Peru. In addition, TPP opens doors for China and South Korea, Thailand and Indonesia who may be future counterparts. In particular, the EVFTA will positively generate more flows of technological transfer, especially connected products and solutions. Imports of connected products, solutions and machinery from the EU to Vietnam and vice versa. In addition to Vietnam- EU trade through EVFTA, Vietnam continues to follow a new generation bilateral agreement such as important provisions for intellectual property (IP) rights, investment liberalization, and sustainable development. More specifically, the EVFTA will significantly increase export performance to the EU for Vietnam's products by roughly 20 percent by 2020, 42.7 percent by 2025 and 44.37 percent by 2030 (MOIT, 2020).

Stimulated by the benefits of economic institutional reform, Vietnam has already entered into several agreements. McCaig \& Pavcnik (2013) conduct on a study, domestic reforms of Vietnam related to the international trade have been followed by international agreement and partnerships. According to Vietnam Chamber of Commerce and Industry (VCCI), about 16 FTAs have been negotiated and signed with almost major economies in the world. It offers more opportunities for domestic firms to enter the larger market since 2000 till today. FTAs and TPP too have lead multinationals to spread in the country in anticipation of business opportunities. Such major existing agreements are ASEAN Free Trade Area (AFTA) and Regional Comprehensive Economic Partnership (RCEP) with China, South Korea, India, Australia and Japan, etc.

\subsection{FDI Inflows performance}

Vietnam has been successful in attracting FDI inflows since the inception of economic reform in 1986. Figure 3 and Figure 4 show that the inflow of FDI has significantly contributed to the economic development of Vietnam in terms of capital, job creation and investment. The Ministry of Planning and Investment concludes that Vietnam has achieved 30,827 valid FDI projects with the total registered capital at US\$ 362 billion and disbursement capital at US\$97.4 billion as well to 2012. For 2013 and 2014, Vietnam has continued to attract FDI at US $\$ 21.6$ billion and US\$22 billion respectively compared to US $\$ 22.76$ billion and US $\$ 24.7$ billion in 2015 and 2016 and more than US $\$ 30$ billion a year in recent years.

Describing FDI inflows to Vietnam during the period of time 1988-2019, Figure 3 shows that actual FDI inflows always account for about haft to a third of the registered FDI inflows every year and this is identified as a problem in the context in which many foreign-owned investors wish to have an assured future for investment rather than in real investments. Accordingly, the year 2008 has been peculiar with FDI inflows breaking a record to US $\$ 72$ billion when many mega-projects have never performed. As a result, by joining WTO in 2007, Vietnam has won some of the giant foreign investors with greater investments. 


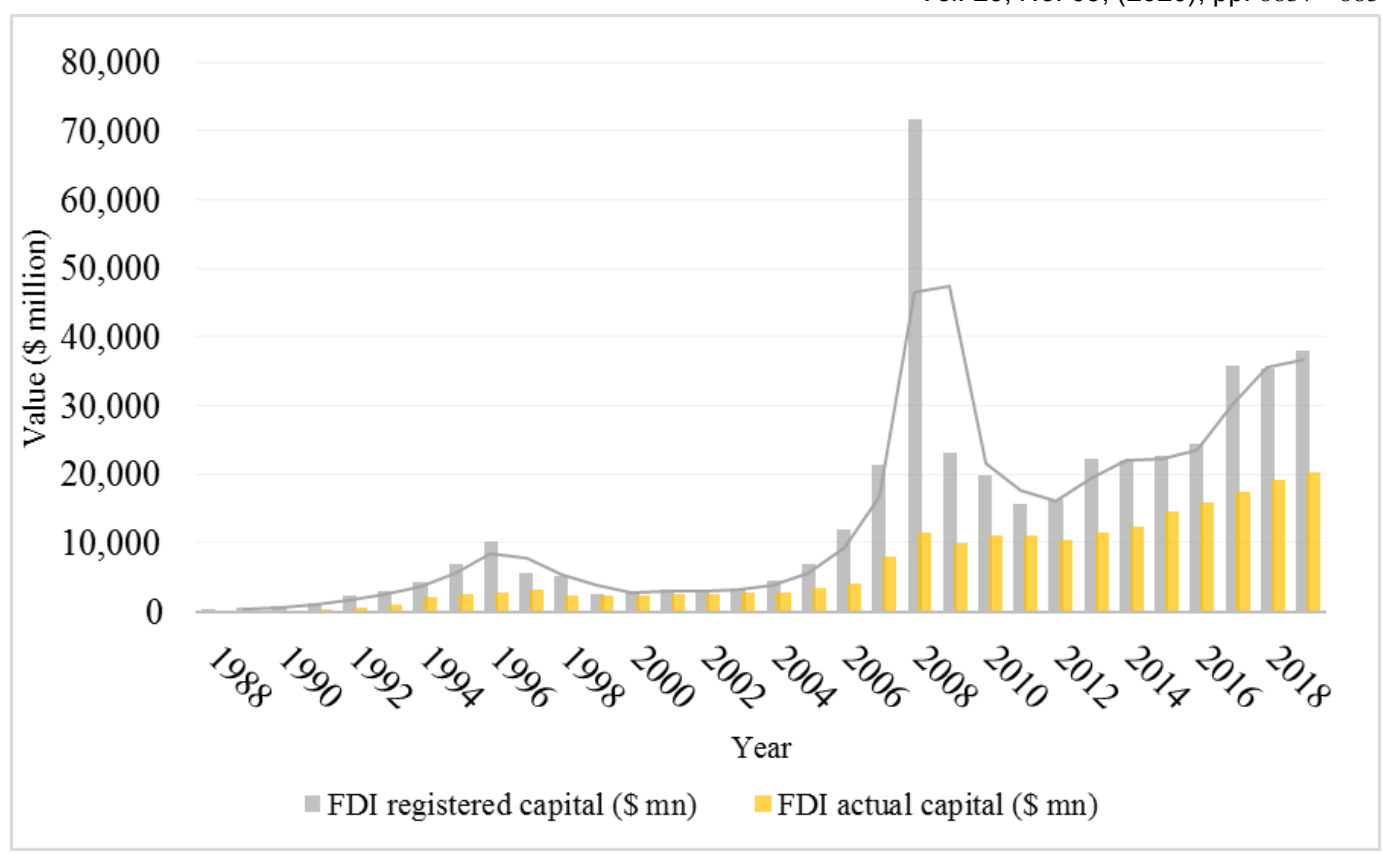

Source: General Statistics Office (2020)

Figure 3. FDI Inflows in Vietnam during the Period 1988 - 2019 (US\$ million)

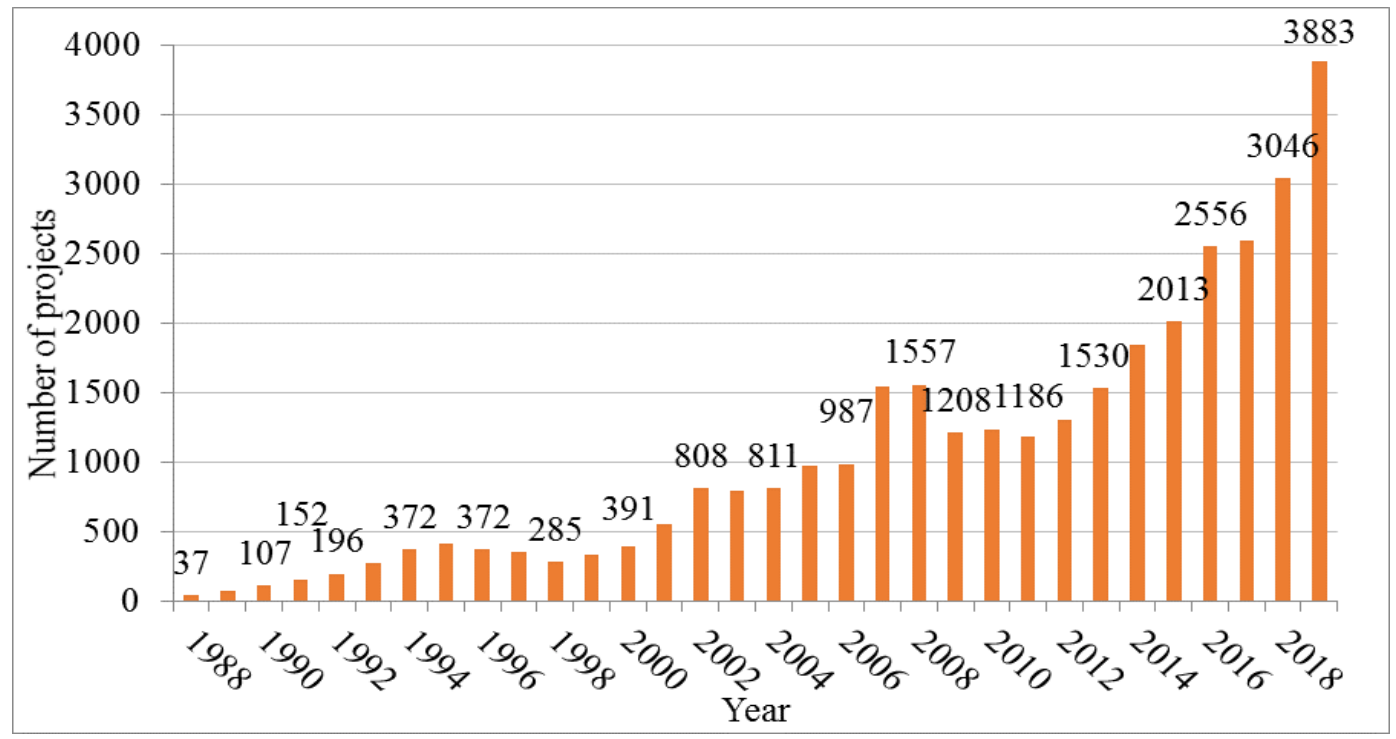

Source: General Statistics Office (2020)

Figure 4. Number of FDI Projects during the Period $1988-2019$

Since 1987, the number of Vietnam's FDI inflows has been in line with the economic reform and the establishment of FDI law especially during the period of time 2000 to the present with approximately 1,114 FDI projects each year, making Vietnam one of the most attractive destinations to FDI flows in Southeast Asia. The number of FDI projects have steadily increased during the years from 1988 - 2019 with over 400 FDI projects on average. Moreover, FDI firms have shown a greater tendency to invest since 2007 with an average of over 1,500 projects a year in comparison with about 300 FDI projects for the stage of 1988 - 2006. Parallel to that, Vietnam has also promoted many FTA negotiations since 2007 to keep this flow. 
Sustaining a high economic growth rate during over last three decades, Vietnam has become the world's low-medium income nation in 2008-09 and its GDP at current prices has sharply increased from US\$8 billion in 1990 to US\$51 billion in 2005 with an estimated US\$225 billion in 2017. However, GDP rate during $1991-2007$ is at average annual rate of 7.64 percent higher than that of in $2008-2019$ at average annual rate of $6 \%$. Empirical evidence also shows that FDI and economic growth have a relationship on both sides in the case of Vietnam. Nguyen (2008) describes that FDI has a positive and statistically significant impact on economic growth during 1996 - 2005 but with the effects that differ from other regions in the country. More specifically, FDI and economic development have mainly been focused on two economic centers in Vietnam. As highlighted by Nguyen \& Nguyen (2007), the economic growth is also a tool to attract FDI inflows.

\section{During the Period 1986 - 1996}

In this period, in addition to the political and economic institution reforms for closing the world, Vietnam has been able to build the country up to the market oriented economy from the closed economy. In general, politicians and the citizens know how to attract FDIs and trade with the world. From the days of commencement with difficulties, FDI investors start exploring and investing in Vietnam which has a large market of 70 million citizens with huge potential, particularly in consumer good production. Though the number of foreign FDIs is established at large, the number of disbursed capital is not high; amounting to US\$200-300 million a year (Figure 3) and 220 annual projects on average (Figure 4). Moreover, most foreign capital concentrates at low technology and simple manufacturing sector for final goods on import substitution (Nguyen, 2018).

One of the most important points for the year 1995 is that, after a 20-year momentum of severed ties, Vietnam and USA official open embassies clearing the path for sound economic relations for both parties. At the same time, FDI inflows boom to US\$10.16 billion registered capital compared to a record level of disbursed capital US $\$ 2.71$ billion in the country in 1996 in accordance with the economic growth rate soared at $9.54 \%$ in 1995 and $9.34 \%$ in 1996.

At this stage, the FDI law has been subjected to amendments in three times over 1990, 1992 and 1996, as in the early stage of the legislative development, it has been essential for Vietnam to adapt to the real situation with improved investment attractiveness over the years.

\section{During the Period 1997 - 2006}

Stable macroeconomics is positively consistent with international flows because foreign investors are to explore potential markets for their business plans. From the years of 1997 - 1999, Hsing (2004) adds that the Asian financial crisis in Thailand in July 1997 with Thai Bath has been collapsed by a monetary attack by hedge funds. At that time, foreign exchange reserve of Thailand has been weak but Thailand's government has been forced to float Thai Bath following a burden of foreign debt and then sudden collapse of Thai Bath. Not only that, Thailand financial crisis that spread over other countries in Southeast Asia, Japan, South Korea, Hong Kong, Laos, Malaysia have been the reason for with slumping currencies and devaluated stock markets.

In contrast to Vietnam market, many foreign capitals from Southeast Asia as Singapore, Thailand, nearby Japan and South Korea, despite Brunei, Vietnam, Singapore and other countries have been less affected though inward FDIs have also devaluated and foreign investors' confidence has been deteriorated due to unexpected problems in the ongoing crisis. For overall, Vietnam has indicated a decrease from US\$372 million in 1996 to a least level of US\$285 million in 1998 , then a few restoration to US\$327 million 
in 1999 (see Figure 3). Beside that economic growth rate has also fallen down during this period (see Figure 4).

In other words, investment environment of Vietnam has not been really attractive due to amendment of a new FDI law that has already reduced some incentives (see Nguyen at el., 2006) for expat investors. Meanwhile Vietnam's neighbor is China has targeted foreign investment aiming the availability of low-cost killed employees and larger market. China has been the top FDI performance in the region to attract these valued inflows (OECD, 2002).

During the period 2000 - 2006, due to the request of development and FDI attraction, Vietnam has revised FDI law to attract more investment to the country, besides, Vietnam has been negotiating to attend WTO and join this organization in Jan 2007 (Nguyen, 2018). In the years of 2000 - 2003, FDI's outcome has been relatively stable by a change of FDI's disbursed inflows of US $\$ 2.4$ billion - US $\$ 2.6$ billion a year, but, from the years of 2004-2006 FDI has been accelerated by the actual capital from US\$2.6 billion in 2003 to US $\$ 4.1$ bn in 2006 compared to US\$3.2 billion in 2003 to US\$12 billion in 2006 of registered capital (see Figure 3).

The quantity of FDI inflows now reaches nearly 1,000 projects (Figure 4). These positive results may be explained by a major reform of the law in 2000 and 2005 as Vietnam has supported more space for foreign investors, allowing for project selection, investment partner selection, form and location as well as clearance of administrative procedures for investors (Tran at el., 2008). In other words, the state also has reduced monopoly in some sectors and supported to foreign investors who could probably be accepted for investment in banking, electricity and insurance. The foreign investment agency of Vietnam has also involved in the domestic and foreign market promotion and explanation of the law of FDI policy with incentives in key areas.

\section{During the Period 2007 - 2019}

A notable shift in FDI attraction is that Vietnam joins WTO in Jan 2007 after many years of negotiation which is a platform for Vietnam's goods to appear in the world as well as for the improvement of the investment environment.

Having estimated in positive effects of WTO, immediately in 2008, FDI inflows break a record in the Vietnam's history. The registered inward FDI has been about US\$71.7bn in 2008; a triple of 2006 and seven times in 2005 with about US\$12 billion (see Figure 3). Particularly, many global foreign investors such as Microsoft in the IT sector, Formosa in the steel sector and Samsung in the electronics sector have explored Vietnam's market for the first time.

In the period of time 2007 - 2011, disbursement of FDI inflows have accelerated over previous duration though the result has been still limited. For example, in spite of receiving much FDI inflows in 2007 and 2008, Vietnam has disbursed only US\$8 billion to US\$11.5 billion in two years, much lower than FDI's promises (see Figure 3). The evaluation of The United of State's USAID on Provincial Competitiveness Index 2010 (PCI 2010) confirm that FDI firms in Vietnam are relatively small in scale and profitable mainly sub-contracting to larger multinationals, therefore acquiring the lowest value in the manufacturing process and global value chain.

At the same time, the environmental issues have also been connected with FDI projects with low technology and pollution in the production sector which are negative remarks for long-term sustainable development in Vietnam. In the case of Taiwan's Vedan and South Korea's Ajinomoto, waste matter has been directly dumped to the river with no treatment putting the lives of fish and fishermen in danger. The bad debt crisis in Egypt, Portugal and the West are also similar examples. The counterparty risk spreads between the banks as well as the sovereign and the banking crisis are serving to exacerbate each other 
(Wignall, 2012), besides that, the problem of USA's bad debt has continued to reach the safe limits, while Japan's economy has been over in over two decade depression affecting to FDI inflows to Vietnam. In contrast to that, inward FDI's disbursement has still been at US\$10-11 billion within the period (see Figure 3) compared to US\$15.6-23.1 billion from 2008-2011 and US\$71.2 billion in 2007 with approximately 1,346 FDI projects a year on average (see Figure 4).

From the years of 2011 - 2014, Vietnam's economic growth rate has slowed down due to many internal problems in the economy. The economy has grown $5.72 \%$ over this entire period, especially a low economic growth rate of 5.25\% in 2012 during the entire renovation period. First NPLs (Non-performing loan ratio) in the banking and financial sector has been opened up to $8.8 \%$ based on the State Bank of Vietnam (SBV). Based on the Decree 254/QĐ/TTg dated 1st Mar 2012 with the proposal of re-organizing credit organizations in the period 2011 - 2015, the rearrangement proposal of financial sector has been underway in 2012 in particular dealing with bad debt in financial institutions and bank. By 2017, some banks still face a high bad debt and low profitability and are still in the progress of restructuring.

Until 2014, the foreign investment law as well as the corporate law has continued to be amended and expanded for the creation of many opportunities for expat investors. By the law, the government has allowed narrowed procedures for FDI investors. Accordingly, Certificate of Investment Registration (CIR) has been valid for the FDI projects with a proportion of more than $51 \%$ foreign capital. All projects with less than $51 \%$ of foreign capital are referred to as local projects and do not require CIR except from Certificate of Business Registration only (CBR) because in the past, FDI law 2005 regulated that regardless of FDI firms with $1 \%$ total equity ownership must have both CIR and CBR. Secondly, the FDI law 2014 clearly explains how regulations of conditional business sectors and this makes foreign investors to understand what sector they are allowed and not. Third, the FDI law 2014 requests a maximum of 15 days for state agencies to approve CIRs for partners. This is a major step in order to reform institutional and attract FDI inflows. Accordingly, by 2019, Vietnam has totally attracted approximately 30,827 valid FDI projects with the total registered capital of USD362 billion.

In connection with a very positive reform program, inward FDI into Vietnam is annually maintained regardless of many internal problems of the economy. Moreover, some big Fortune 500 investors have expanded in Vietnam. The economy has gradually changed from a highly labor-intensive industries to a higher capital-intensive industries related to giant multinationals. The electronics and telecommunication have become the major concern while exporting trend of textiles in export structure and apparel has steadily slowed.

\section{Conclusion}

Foreign direct investment has importantly played a decisive role in growth, as a tool to finance development, transfer of technology and development, employment creation, human-resource quality enhancement and increase the volume and the value of export in host countries. In the late 1980s under the policy of renovation, political and economic reforms, Vietnam has considerable potential to attract significantly more foreign investment. Significantly, Vietnam has undergone such an impressive process of transformation from an isolated, less developed and agriculture based economy into a booming nation with more foreign investment.

Resulted by Doimoi, and especially the positive effects of Vietnam - USA relationship, the economic and political reforms have attempted in an effort to lift the nation by eradicating famine, poverty, and encouraging export led growth strategy in favor of import substitution. Vietnam has transformed its economy from a central planning 
economy to a socialist-oriented market economy. Foreign Investment Rules, Foreign Investment Law introduced in the first time in 1987 and other FDI revised law, Enterprise Law and late Investment Law has strongly supported FDI inflows in the country.

Vietnam's success predominantly supported by the participation of FTAs and other trade agreements, further managed to attract significant inflows of FDI quickly through the establishment of Industrial Parks (IPs) and Export Processing Zone (EPZ) across the country. In addition, the Comprehensive and Progressive Agreement for Trans-Pacific Partnership (CPTPP), and Vietnam- EU free trade agreements, the benefits of the trade agreements is about to enable economic development to continue to welcome more hightech FDI projects as well as to shift away from primary or raw goods and exporting lowtech manufacturing products to more sophisticated high-tech goods like electronics, machinery, vehicles, medical devices and other high-tech products.

\section{Acknowledgments}

We thank Senior Lecturer, Dr. Priyanga Dunusinghe, Department of Economics, Faculty of Arts, University of Colombo for his useful comments.

\section{References}

[1] Aitken, B., Hanson, G.H., and Harrison, A. E. (1997). Spillovers, Foreign Direct Investment and Export Behavior. Journal of International Economics, 43(1-2), pp. 103-132.

[2] AmCham Vietnam (2016). Vietnam's Economy increasingly relies on FDI exports. American Chamber of Commerce Vietnam, Ho Chi Minh City, Vietnam.

[3] Chaudhry, N.I., Mehmood, M.S., Mehmood, A. (2013). Empirical Relationship between Foreign Direct Investment and Economic Growth: An ARDL Co-integration Approach for China. China Finance Review International, 3(1), pp 26-41.

[4] Cling, J.P. at el. (2008). Vietnam's Terms of Accession and Distributional Impact of WTO Membership. Development Institutions and Analyses de Long terme, Paris, France.

[5] Dasgupta, P. \& Mukhopadhyay, K. (2017). The Impact of the TPP on Selected ASEAN Economies. Journal of Economics Structures, 6, 26 (2017). https://doi.org/10.1186/s40008017-0086-7.

[6] Du, L., Harrison, A. \& Jefferson, G.H. (2011). Testing for Horizontal and Vertical Foreign Investment Spillovers in China. Journal of Asian Economics, 23(3), pp 234-243.

[7] Frankel, J. \& Rose, A. (2002). An Estimate of the Effect of Common Currencies on Trade and Income. The Quarterly Journal of Economics, 2(1), pp 437-446.

[8] Froman, M. 2016). United States - Vietnam Plan for the Enhancement of Trade and Labor Relations. Washington DC, USA, linked at https://ustr.gov/sites/default/files/TPP-Final-TextLabour-US-VN-Plan-for-Enhancement-of-Trade-and-Labour-Relations.pdf

[9] Harrison, A. (1994). Productivity, Imperfect Competition and Trade Reform. Theory and Evidence. Journal of International Economics, 36, pp 53-73.

[10] Harrison, A.E. \& Rodríguez-Clare, A. (2010). Trade, Foreign Investment and Industrial Policy for Developing Countries. Handbook of Development Economics, 5, pp. 4039-4214.

[11] Helpman, E., Meliz, M.J. \& Yeaple, S.R. (2004). Export versus FDI with Heterogeneous Firms. American Economic Review, 94(1), pp. 300-316.

[12] Hsing, H.M. (2004). Leading Indicators of Asian Currencies Crisis-the Weighted Signal Approach. Asia Pacific Management Review, 9(1), pp. 119-136.

[13] Le, D.D. (2002). Foreign Direct Investment in Viet Nam: Results, Achievements, Challenges and Prospect. International Monetary Fund Conference on Foreign Direct Investment Hanoi. August 16-17, 2002.

[14] McCaig, B. \& Panvnik, N. (2013). Moving out of Agriculture: Structural Change in Vietnam. NBER Working Paper. No. 19616, Nov 2013.

[15] MOIT (2020). The general introduction to EVFTA and IPA. Department of EuropeanAmerican Market, Ministry of Industry and Trade.

Available at http://evfta.moit.gov.vn/?page=overview\&category id=fb203c7b-54d6-4af785ca-c51f227881dd

[16] Mun, H.W., Lin, T.K., Yee, K.M. (2008). FDI and Economic Growth Relationship: An Empirical Study on Malaysia. International Business Research, 1(2), pp 11-18. 
[17] Nguyen, A.N. \& Nguyen, T. (2007). Foreign Direct Investment in Vietnam: An Overview and Analysis of the Determinant of Spatial Distribution across Provinces. Development and Policies Research Center. Working Paper, Hanoi, Vietnam

[18] Nguyen, P.L. (2008). Absorptive Capacity, Foreign Direct Investment and Economic Growth in Vietnam. International Graduate School of Business, $\mathrm{PhD}$ thesis, University of South Australia.

[19] Nguyen, T.A. at el. (2006). The Effects of Foreign Direct Investment to Economic Growth in Vietnam. Central Institute for Economic Management, Hanoi.

[20] Nguyen, C. (2018). Foreign Direct Investment, Productivity and Export Participation: The case of Vietnam's Manufacturing Sector. Department of Economics, Colombo University.

[21] Nguyen, V. (2020a). Human capital, capital structure choice and firm profitability in developing countries: An empirical study in Vietnam. Accounting, 6(2), 127-136. http://dx.doi.org/10.5267/j.ac.2019.11.003

[22] Nguyen, V.C. (2020b). Energy consumption, income, trading openness, and environmental pollution: Testing environmental Kuznets curve hypothesis. Journal of Southwest Jiaotong University, 55 (1), 1-10. https://doi.org/10.35741/issn.0258-2724.55.1.6

[23] Nikkei (2017). Vietnam and Malaysia play vital roles in making TPP 11 happen. Nikkei Asian Review, linked at https://asia.nikkei.com/Politics-Economy/InternationalRelations/Vietnam-and-Malaysia-play-vital-roles-in-making-TPP-11-happen

[24] OECD (2000). Main Determinants and Impact of Foreign Direct Investment on China's Economy. Working Papers on International Investment. 2000 (4). OECD Publishing. https://doi.org/10.1787/321677880185

[25] OECD (2002). Foreign Direct Investment for Development: Maximum Benefits and Minimum Costs. OECD Publications Service, Paris, France.

[26] Petri, P.A. \& Plummerm, M.G. (2016). The Trans Pacific Partnership and Asia-Pacific Integration: Policy Implications. Policy Brief, No.PB12-16, Peterson on Institute for International Economics.

[27] Pham, T.H.H. (2011). Does WTO Accession Matters for the Dynamics of Foreign Direct Investment and Trade? Economics of Transition, 19(2), pp 255-285.

[28] Schellhorn, K.M. (1992). Political and Economic Reforms in Vietnam. Contemporary Southeast Asia, 14(3), pp. 231-243.

[29] Subramanian, A. \& Wei, S. (2003). The WTO Promotes Trade, Strongly but Unevenly. IMF Working Paper. No.03/185, September.

[30] Tybout, J. R. (2000). Manufacturing Firms in Developing Countries: How Well Do They Do, and Why? Journal of Economic Literature, Vol. XXXVIII, pp. 11-44.

[31] Van, N.C. \& Do, T.T. (2020). Impact of Exchange Rate Shocks, Inward FDI and Import on Export Performance: A Cointegration Analysis. Journal of Asian Finance, Economics and Business, 7 (4).

[32] Wang, J. (1990). Growth Technology Transfer, the Long-Run Theory of International Capital Movements. Journal of International Economics, 29(3-4), pp 255-271.

[33] Wignall, A.B. (2012). Solving the Financial and Sovereign Debt Crisis in Europe. OECD Journal: Financial Market Trends, OECD Publishing, 2011(2), pp. 201-224.

[34] World Bank (2010). Foreign Direct Investment - the Story of China. July 16, 2010. https://www.worldbank.org/en/news/feature/2010/07/16/foreign-direct-investment-chinastory

[35] World Bank (2011). Vietnam Development Report 2012: Market Economy for a Middle Income Vietnam. Washington, D.C.: World Bank Group. 